A N N A LES

UNIVERSITATIS MARIAE CURIE-SKŁODOWSKA

LUBLIN - POLONIA

VOL. XXVIII, 1

SECTIO J

2015

Uniwersytet Rzeszowski

Instytut Pedagogiki

\title{
KRYSTYNA BARŁÓG
}

krystyna_barlog@tlen.pl

\section{Trajektoria $w$ analizach cierpienia osób z nagła utratą sprawności}

Trajectory in the analyses of the suffering of people with a sudden loss of ability

\section{STRESZCZENIE}

Zgodnie z osiągnięciami współczesnej nauki, zwłaszcza medycyny, psychologii, genetyki czy pedagogiki specjalnej, człowiek - jako główny z bytów we współczesnym świecie - jest zdolny do pokonywania wielu ograniczeń i problemów, kryzysów egzystencjalnych, sytuacji trudnych, bólu i cierpienia. Pojawienie się nagłej niepełnosprawności zmienia jednak całkowicie jego sytuację, powodując wiele negatywnych przeżyć. Jest to proces trajektoryjnych zmagań z lękiem, odrzuceniem, samotnością i poszukiwaniem wartości cierpienia, ale i próba akceptacji własnej osoby w nowych rolach i zadaniach oraz ograniczeniach egzystencji.

Słowa kluczowe: nabyta niepełnosprawność, kryzysy egzystencjalne, proces trajektoryjnych zmagań

Niepełnosprawność, choroba, cierpienie jest wyzwaniem naszych czasów, któremu współczesne społeczeństwo nadal nie potrafi sprostać. Mimo wielu osiągnięć wciąż niewystarczające i nieefektywne są działania pomocowe, wspierające, rehabilitacyjne czy psychologiczne zapobiegające cierpieniu człowieka. Współczesna nauka często już formułuje tezę, że człowiek dzisiaj, jako jeden z głównych bytów we wszechświecie, zdolny jest do pokonywania sytuacji traumatycznych, różnorodnych kryzysów, traumy, nieprzewidywalnych, trudnych 
sytuacji czy zdarzeń. W zasadzie powszechnie przyjmuje się, że człowiek zdolny jest do przystosowania się, adaptacji do różnorodnych sytuacji „bez wyjścia”, pokonywania wielu ograniczeń związanych z ludzką egzystencją. Osoby niepełnosprawne o silnym przekonaniu co do możliwości uzyskania oczekiwanego wsparcia ze strony innych mają większe poczucie bezpieczeństwa oraz pozytywnie formułują cele i perspektywy na przyszłość.

Współczesna medycyna, psychologia czy pedagogika specjalna podejmują problem człowieka w ujęciu holistycznym, systemowo, z przyjęciem, że nagle powstające, traumatyczne sytuacje życiowe należy odnieść do całej natury ludzkiego życia. Z ekologicznej i systemowej perspektywy rozwoju szczególnie istotne są tu relacje, interakcje w sytuacji nagłej utraty sprawności osoby poszkodowanej z jej dążeniami, celami, wyzwaniami, całym mikrosystemem osób jej bliskich, systemem rodzinnym, grupą przyjaciół, najbliższym środowiskiem jako przestrzenią zrozumienia, opieki, pomocy i wsparcia.

Najprościej mówiąc, osoba chora chce tylko porozmawiać, pragnie pocieszenia, zrozumienia, potrzebuje niewiele - w milczeniu być razem z kimś bliskim (Zych, Nowicka 2007, s. 17).

\section{PROBLEM NAGŁEJ UTRATY SPRAWNOŚCI}

Nagła utrata sprawności to wydarzenie przełomowe, wymagające zmiany w postrzeganiu siebie i świata na każdym z poziomów funkcjonowania człowieka - towarzyszą jej negatywne emocje i bariery, a także trudności w psychospołecznym funkcjonowaniu.

Jest to sytuacja nieoczekiwana, nowa i zarazem bardzo ważna, stanowi przyczynę silnego stresu, wymaga wiele energii koniecznej do poradzenia sobie i przetrwania traumy (Wolski 2010, s. 25).

Obecność nagłej niepełnosprawności „wiąże się z określonymi negatywnymi konotacjami. Są one odbierane jako skutki niepełnosprawności i pojawiają się w trzech głównych poziomach: doświadczeniowym, behawioralnym oraz społecznym" (Wiliński 2010a, s. 62). Pojawia się więc zależność od innych, poczucie bycia kimś mniej wartościowym, deprywacja zdolności do działania. Jest to trudny proces zmian, etapów, psychologicznych konsekwencji utraty sprawności i radzenia sobie z nową, jakże teraz odmienną rolą czy sytuacją.

Oczekiwana jest wówczas modyfikacja otoczenia w celu zaspokojenia własnych, indywidualnych potrzeb, a system przekonań jednostki w sposób znaczący wpływa na przyjęcie postawy aktywnej lub biernie poddającej się zaistniałej sytuacji.

Niepewność siebie, w odniesieniu do własnych możliwości, ograniczeń i relacji społecznych, związana z niewiedzą na temat własnej niepełnosprawności, naraża na przeżywanie stanów frustra- 
cji. W konsekwencji nagromadzenie frustrujących sytuacji może prowadzić do agresywnych reakcji lub wręcz przeciwnie - do wycofania się z jakichkolwiek działań, tj. reakcji unikowej (Wolski 2010, s. 26).
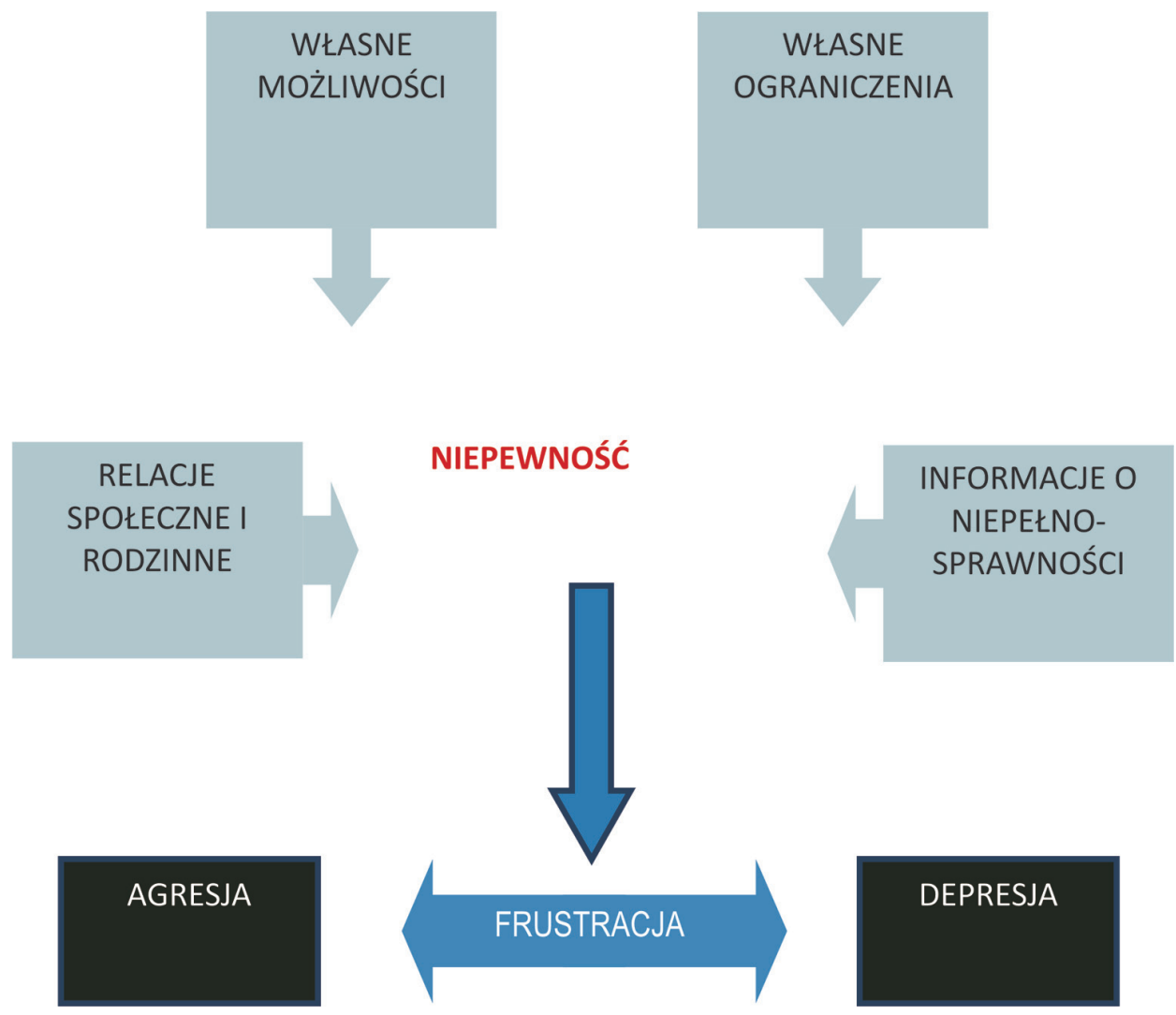

Ryc. 1. Schemat przyczyn i skutków nagromadzenia niepewności w wyniku nabycia niepełnosprawności (Wolski 2010, s. 25)

Zmianie ulegają również cele, zadania życiowe i wartości z tendencją do depresji, stosowania mechanizmów obronnych, poczucia ,ja” czy własnej tożsamości (ryc. 2).

Dla zachowania wzajemnej równowagi potrzeb i ograniczeń wynikających z nagłej utraty sprawności oczekiwana jest mobilizacja sił, pogodzenie się z zaistniałą już sytuacją i próba przystosowania się do nowych okoliczności, problemów, sytuacji, zmian w obrębie całego systemu rodzinnego, systemu potrzeb i celów, systemu wartości.

Ograniczenia sprawności mogą być na tyle duże, że będą całkowicie lub znacznie blokować podejmowanie przez nią ról społecznych, wyłączać daną jednostkę $\mathrm{z}$ wielu obszarów działania 


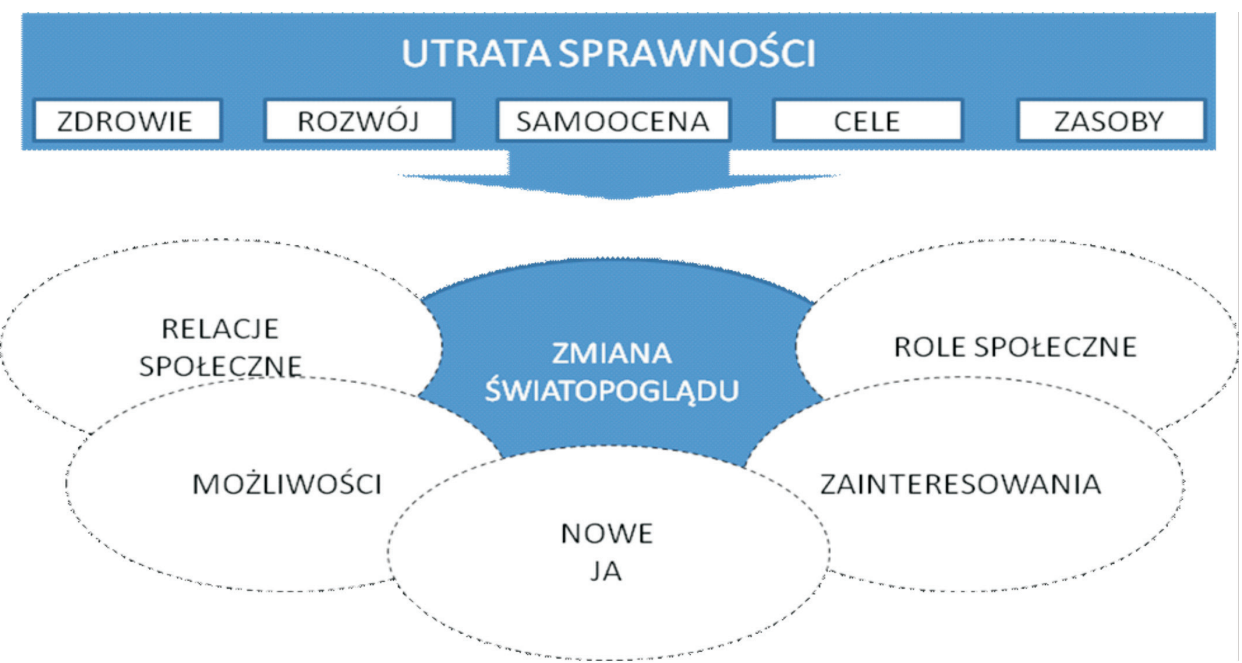

Ryc. 2. Zmiana światopoglądu w obliczu utraty sprawności (Wolski, za: Kowalik 2003, s. 26)

typowych dla jej rówieśników, a także powodować takie ograniczenie jej samodzielności, że zaspokajanie podstawowych życiowych potrzeb wymaga nieustannej pomocy opiekuna. Problemy komplikują się znacznie, gdy dane ograniczenie sprawności jest nietypowe, zdarza się bardzo rzadko, a sama doświadczająca go osoba, jak i jej najbliższe otoczenie nie dysponują wiedzą na temat możliwych, a jednocześnie dostępnych, nie tylko finansowo, sposobów postępowania leczniczego i rehabilitacyjnego, oraz wsparcia psychologicznego i społecznego (Brzezińska, Kaczan, Smoczyńska 2010, s. 11).

Często mogą to być choroby neurologiczne, upośledzenie narządu ruchu, choroby układu pokarmowego, oddechowego, krążenia czy inne. Problemem jest pomoc w przystosowaniu się do nowej sytuacji traumatycznej, akceptacja własnej niepełnosprawności, bez względu na stopień czy rozległość uszkodzenia, pomoc w przystosowaniu się do wynikających z ograniczenia problemów.

Kulturowym stereotypem w naszym społeczeństwie jest też człowiek eksponujący się przez milczenie, z piętnem smutku lub wstydu i zatajeniem swojego złego samopoczucia oraz cierpienia spowodowanego obawą przed odrzuceniem, mimo wielu kłopotliwych problemów osobistych. Otwartość spostrzegana jest jako słabość, niedojrzałość i naiwność lub też nieuzasadniony ekshibicjonizm (Dykcik 2007, s. 125).

Jak potwierdza J. Kirenko (2002, s. 60), ,świat jest urządzony przede wszystkim dla pełnosprawnych ludzi, którzy stają się najczęściej sztywni i skrępowani, kiedy przyjdzie im spotkać osoby niepełnosprawne. Niechęć wobec niepełnosprawnych przejawia się głównie w postaci stereotypów piętnowania oraz konkretnych postaw negatywnych". 
W literaturze przedmiotu można spotkać się z kilkoma ujęciami cierpienia. Mowa tu o podejściu socjologicznym, filozoficznym, religijnym czy etycznym. W definiowaniu cierpienia najczęściej przyjmuje się, że jest częścią i elementem ludzkiego życia, ludzkiej natury. Cierpienie towarzyszy ludzkości od początku jej istnienia i dotyka wszystkich, przy czym dla jednych jest jedynie krótkim epizodem, innym towarzyszy przez całe życie (por. Olearczyk 2007, s. 99). Jest pojęciem niezmiernie szerokim, wielowymiarowym i zróżnicowanym tematycznie, co utrudnia jego jednoznaczne zdefiniowanie. Do pojęć tego rodzaju używanych zamiennie można zaliczyć: ból, dolegliwość, męka itp. Pojęcie cierpienia nie jest jednak tożsame z pojęciem bólu, gdyż jego znaczenie jest szersze i pełniejsze. W filozoficznej perspektywie cierpienie ,jest czymś innym niż ból, a także czymś więcej niż ból", gdyż ma ono charakter duchowy, moralny, estetyczny i egzystencjalny. Rzutuje „,na nasze relacje ze światem zewnętrznym, zarówno tym przedmiotowym, jak i ludzkim" (Cackowski 1997, s. 33-34).

Różne są źródła ludzkiego cierpienia. Dla osoby cierpienie jest przykrym doświadczeniem, nieoczekiwanym i niepożądanym, nawet destrukcyjnym. W sytuacji cierpienia człowiek doświadcza faktu własnej niedoskonałości, nic innego się nie liczy, życie traci sens. Przyczyną cierpienia może być nagła utrata sprawności, nagłe ograniczenia człowieka, potrzeby i problemy. Łagodzenie cierpienia może mieć miejsce jedynie w obecności drugiej osoby, jej wrażliwości, empatycznym wczuwaniu się, umiejętności zrozumienia potrzeb i sytuacji. W ujęciu V. Frankla „byt ludzki jest ostatecznie cierpieniem, i istotnym przeznaczeniem człowieka jest - cierpieć: by być homo patiens". W jego ujęciu cierpienie ma sens, a znosząc cierpienie, człowiek dojrzewa moralnie, bogaci się, kształtując samego siebie (por. Frankl 1984, s. 74-75).

Sytuacja nagłej utraty sprawności łączy się z cierpieniem, niepewnością, lękiem, przybierając formę procesu dokonujących się negatywnych zmian, emocji, celów umiejscowionych w kolejnych etapach przemian osoby niepełnosprawnej.

\section{KIM JESTEM}

W sytuacji nagłej utraty sprawności, szczególnie w wypadku widocznego ograniczenia sprawności, pojawia się wiele pytań egzystencjalnych, dotyczących usytuowania osoby z niepełnosprawnością w jej psychospołecznym funkcjonowaniu. Wynikają z nich pewne konsekwencje psychospołeczne obejmujące:

- „wyższy poziom stresu życiowego,

- obniżony nastrój,

- wewnętrzne bariery utrudniające podejmowanie kontaktów społecznych,

- wyższy poziom lęku, 
- częstsze automatyczne myśli negatywne (np. »Jestem do niczego«),

- trudności w poszukiwaniu i podejmowaniu pracy,

- a w konsekwencji niski poziom subiektywnego poczucia jakości życia” (Bedyńska, Rycielski 2010, s. 95).

W takiej traumatycznej sytuacji następuje zaburzenie poczucia tożsamości i przeformułowanie dotychczasowych celów życiowych, wartości, utraconych szans czy planów, co w konsekwencji może prowadzić do syndromu wyuczonej bezradności i braku chęci i sensu życia. Przeżywanie stanów frustracji, zaprzepaszczonych nadziei i celów może ostatecznie prowadzić do rezygnacji, wycofywania się z wielu dotychczasowych aktywności czy uruchamiania mechanizmów obronnych dla złagodzenia trudnych informacji, które docierają do świadomości.

\section{TRAJEKTORIA - WYMIARY CIERPIENIA}

Pojęcie trajektorii zostało wprowadzone do badań nad cierpieniem pod koniec lat sześćdziesiątych XX wieku przez Glasera i Straussa. Jest to „metafora nawiązująca do lotu kuli, pocisku, pojazdu kosmicznego" (Dobrowolska 1992, s. 75). Inaczej trajektoria to proces przemian, to „,koncepcja stanowiąca podstawową kategorię odnoszącą się do badania bezładnych procesów społecznych i procesów cierpienia, a więc zjawisk, które ze swojej istoty nie poddają się analizie socjologicznej, stosującej standaryzowane metody obróbki danych" (Zakrzewska-Manterys 1995, s. 18).

Również D. Dobrowolska przyjmuje, że pojęcie trajektorii stosowane bywa „,na oznaczenie jednak nie tylko przebiegu całego życia, ile poszczególnych jego odcinków lub aspektów (choroby, procesu umierania, zmiany statusów" (Dobrowolska 1992, s. 75-76). Glaser i Strauss opracowali koncepcję trajektorii umierania. Strauss definiuje trajektorię choroby jako „fizjologiczny przebieg choroby danej jednostki wraz z całą organizacją pracy, która ma być w związku z tym wykonana" (Strauss 1989, s. 224). Wspólnie opracowali kategorię trajektorii umierania wyłącznie do procesu umierania.

Jako nowatorska koncepcja teoretyczna, kategoria pojęciowa zaprezentowana w kontekście medycznym oraz socjologicznym trajektoria dotyczyła głównie analizy doświadczeń osób stojących przed wyzwaniem opanowania choroby. Przedmiotem tej koncepcji była głównie zmiana statusów. Wymiary zmiany statusów wskazywane przez badaczy problemu to: zmiana pożądana - niepożądana; nieuchronna lub nie; odwracalna lub nie; dotycząca jednej osoby lub grupy osób; wyrażająca się w sygnałach wyraźnych lub mało widocznych; zmiany dokonuje się dobrowolnie lub ze względu na zaistniałe okoliczności; posiadanie kontroli nad dokonującą się zmianą lub nie (Zakrzewska-Manterys 1995).

Trajektorię traktowano jako pojęcie zawierające opis i analizę umierania, przyjmując, że przebieg trajektorii zależy od osobowości jednostki z założeniem, 
że zabiegi stosowane, mające zadanie leczenia, powstrzymywania postępu choroby, stają się zabiegami, których celem jest zminimalizowanie odczuwanego przez pacjenta bólu, co potwierdza przejście pacjenta z roli osoby chorej do roli osoby umierającej (por. Zawiła 2008). Pojęcie trajektorii można dziś zaproponować również do analizy innych, różnorodnych problemów, które nie zawsze są związane z procesem umierania. Koncepcja trajektorii generalnie służy do badania zmienności przebiegu życia ludzkiego bez względu na to, czy analizowana zmienność przybiera charakter porażki, czy sukcesu (Górecki 2007a).

Szerzej koncepcję trajektorii cierpienia ujmują Rieman i Schutze, przyjmując, że koncepcję trajektorii należy rozumieć jako „bezładne procesy społeczne i procesy cierpienia: kategoria ta umożliwić ma identyfikację, zrekonstruowanie i zrozumienie fenomenów, których rozpoznanie zostało zaniedbane w większości badań” (Riemann, Schutze 1992, s. 92). Wydaje się, że zastosowanie uogólnionej koncepcji trajektorii umierania uzasadnione jest więc w przypadku, kiedy „badacz styka się z nieuporządkowanym, chaotycznym zjawiskiem i strategiami radzenia sobie z tą rzeczywistością, która nie jest ujęta w innych socjologicznych schematach" (Lewandowska 1997, s. 443). To również uchwycenie zewnętrznych ram, wewnątrz których sam podmiot dokonuje analizy i diagnozy tego, co mu się osobiście i bezpośrednio przytrafia (por. Rieman, Schutze 1992). Dotknięty trajektorią człowiek ,ma jakby dwie biografie. Pierwsza przeżywana jest, zanim człowiek wszedł w trajektorię, oraz druga - niekiedy całkowicie inna - biografia, która rozpoczyna się po wyjściu z niej” (Nowak-Lińska 2007, s. 186).

\section{MODELE TRAJEKTORII CIERPIENIA}

W trajektoryjnej strukturze wyodrębnionych etapów, narastającego potencjału badawczego model ich przebiegu prezentuje F. Schutze (1997). Autor ten wyodrębnia następujące stadia i mechanizmy rozwijającej się trajektorii:

a) gromadzenie się potencjału trajektoryjnego - najczęściej bywa tak, że osoba dotknięta problemem trajektorii cierpienia na początku nie zdaje sobie sprawy z nagle powstałego problemu, a jednocześnie sama potrafi wskazać na pewne symptomy zbliżającej się trajektorii;

b) przekroczenie granicy - „osoba dotknięta problemem nie jest już w stanie kształtować swego życia codziennego poprzez aktywne schematy działania" (Schutze 1997, s. 25);

c) rozwinięcie chwiejnej równowagi radzenia sobie z życiem codziennym, dzięki któremu stan i zamęt mogą zostać przezwyciężone, a nowe życie zostaje jednak nadal niestabilne, gdyż najważniejsze determinanty trajektorii nie mogą być właściwie zdefiniowane; 
d) destabilizacja równowagi - osoba dotknięta trajektorią staje się sama sobie obca: to nagłe nagromadzenie się traumatycznych problemów całkowicie zmienia oczekiwania i sytuacje;

e) próby teoretycznego przepracowania załamania się orientacji oraz trajektorii - osoba dotknięta trajektorią odczuwa całkowitą niezdolność do działania, cechuje ją wyobcowanie i brak zgody na zastaną sytuację, co zmusza do analizy własnej, nowej sytuacji życiowej. Zaprezentowane definicyjne ujęcie trajektorii cierpienia wskazuje na trzy wymiary:

- wyjaśnienia procesów cierpienia,

- oceny moralnej,

- analizy wpływu procesów cierpienia na teraźniejszy i przyszły sposób życia (Schutze 1997).

Jednocześnie F. Schutze (1997) wskazuje trajektorię jako jedną z czterech struktur procesów życia. Poza trajektorią wskazuje na:

- „wzorce instytucjonalne (sekwencje biograficzne, w których jednostka orientuje się na realizację społecznych oczekiwań wynikających z norm instytucjonalnych),

- biograficzne schematy działania (działania mające na celu realizację zamierzenia),

- przemiany ( procesy, w których projekty biograficzne jednostek koncentrują się wokół zmiany tożsamości)" (Ślęzak 2005, s. 305).

Stadia rozwoju trajektorii z uwzględnieniem, że każdy strukturalny proces biograficzny ma własny porządek sekwencyjny, według Reimann i Schutze (1992) są następujące:

1. Stopniowe gromadzenie się potencjału trajektoryjnego - proces narastania trajektorii rzadko rozpoczyna się nagle i nieoczekiwanie, przy czym wyjątek stanowi tu nagłe stwierdzenie poważnej choroby. Osoba w trajektorii powoli dostrzega pierwsze jej oznaki. Bardzo powoli, ale systematycznie trajektoria powiela swój potencjał, gromadząc niekorzystne wpływy wokół swojej ofiary. Mimo iż osoba nią dotknięta stara się wyprzeć ją ze świadomości, następuje narastanie procesu trajektoryjnego (Górecki 2007).

2. Nagłe przekroczenie granicy uczynnienia potencjału trajektoryjnego. Towarzyszy temu procesowi sytuacja szoku i dezorientacji. Następuje splot wydarzeń, które dynamizują potencjał trajektoryjny, jednostka nie jest w stanie na tę sytuację reagować (Schutze 1997, Górecki 2007).

3. Próba radzenia sobie z życiem codziennym, przezwyciężenie szoku i następnie stanu zamętu. Utrzymanie chwiejnej równowagi, pozostającej jednak pod wpływem trajektoryjnego potencjału, który nie jest poddany kontroli (Schutze 1997).

4. Pojawienie się destabilizacji chwiejnej równowagi w radzeniu sobie z wyzwaniami dnia codziennego - osoba nadmiernie koncentrując się na jednym 
aspekcie problemu, pomija pozostałe, które przybierają postać skumulowanego nieładu; następuje zwiększenie mocy trajektorii i jej potencjału (Górecki 2007, Schutze 1997).

5. Załamanie się organizacji życia codziennego. Jednocześnie następuje załamanie się orientacji wobec samego siebie, dochodzi do nagłego nagromadzenia się problemów życiowych, falsyfikacji ustalonego planu oczekiwań, co przechodzi w stan utraty zaufania i do siebie, i do innych, a jednocześnie oczekiwania pomocy i wsparcia (Górecki 2007).

6. Próba racjonalizacji trajektorii i pogodzenia się z nią - w tej sytuacji osoba stara się scharakteryzować swoją sytuację, redefiniuje swoje położenie, próbuje odnaleźć źródła cierpienia. Jest to działanie ryzykowane i może pozbawić jednostkę moralnej odwagi życia, a może być próbą opanowania jej dynamiki (Ślęzak 2005, Górecki 2007).

7. Praktyczna praca nad trajektorią i powrót do życia (Zakrzewska-Manterys 1995).

Inny model trajektoryjny, zwany modelem etapowego radzenia sobie z utratą sprawności, bezpośrednio odwołujący się do sytuacji utraty sprawności, prezentuje P. Wolski (2010), podejmując próby ukazania możliwości radzenia sobie z niepełnosprawnością nabytą. Poniżej zaprezentowane są etapy tego procesu wraz z towarzyszącymi im emocjami i zachowaniami. Są to: etap 1 - szok i zaprzeczanie, etap 2 - gniew, etap 3 - targowanie się, etap 4 - depresja, etap 5 - akceptacja.

Według Reimann i Schutze (1992) wszystkie badane trajektorie biograficzne można scharakteryzować za pomocą następujących cech:

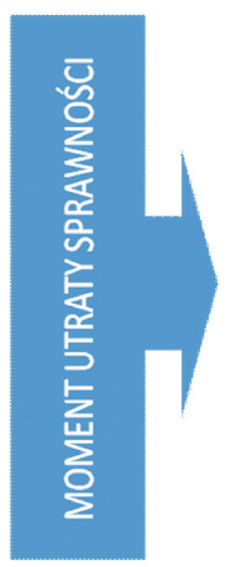

\begin{tabular}{l|}
\hline SZOK \\
\hline ZAPRZECZANIE \\
\hline STRES \\
\hline ZAL DO ŚWIATA \\
\hline OBRONAJA IDEALNEGO \\
\hline NIEREALNY OPTYMIZM \\
\hline RACJONALIZACJA \\
\hline LEK
\end{tabular}

Ryc. 3. Cechy charakterystyczne etapu szoku i zaprzeczania Źródło: Wolski 2010, s. 29. 


\begin{tabular}{|c|c|}
\hline & ROZŻALENIE \\
\hline 응? & GNIEW \\
\hline Z & FRUSTRACJA \\
\hline 岕它 & ZŁOŚĆ NA ŚWIAT \\
\hline 疍 웅 & ZŁOŚĆ NA SIEBIE \\
\hline 岁 욮 & POCZUCIE BEZRADNOŚCI \\
\hline 辰学 & POCZUCIE PORAŻKI \\
\hline & POSTAWA ROSZCZENIOWA \\
\hline
\end{tabular}

Ryc. 4. Cechy charakterystyczne etapu gniewu

Źródło: Wolski 2010, s. 30.

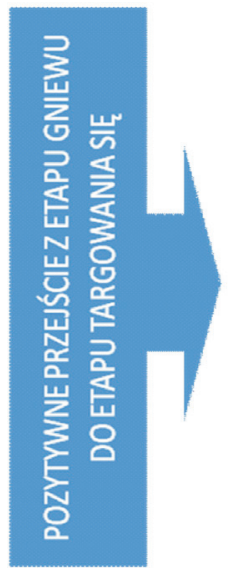

\begin{tabular}{l}
\hline POWRÓT NADZIEI \\
ZEWNAZTRZSTEROWNOŚĆ \\
POSZUKIWANIE LEPSZEJ DIAGNOZY \\
POSZUKIWANIE NOWYCH METOD LECZENIA \\
POSTANOWIENIA PROZDROWOTNE \\
\hline KONFLIKT KOGNITYWNO-AFEKTYWNY \\
UCIECZKA W WIARE \\
\hline
\end{tabular}

Ryc. 5. Cechy charakterystyczne etapu targowania się

Źródło: Wolski 2010, s. 32.

- przytłoczona nieoczekiwanymi wydarzeniami jednostka uświadamia sobie, że nie może już polegać na swoich oczekiwaniach co do wydarzeń określających przebieg jej życia;

- jednostka odczuwa siebie jako ofiarę potężnych zewnętrznych mocy, których nie może ani zrozumieć, ani kontrolować;

-źródła owych mocy są dla jednostki niepojęte;

- rozkojarzenie orientacji, które prowadzi do poczucia oddzielenia od zewnętrznego świata normalnej egzystencji; 


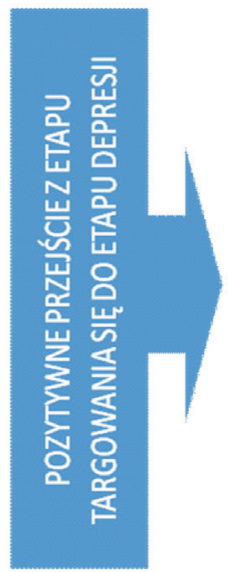

\begin{tabular}{l} 
OBNIŻENIE NASTROJU \\
REAKCJA DEPRESYJNA \\
POCZUCIE NIEODWRACALNOŚCI WŁASNEGO STANU \\
REZYGNACJAZ DZIAŁAŃ \\
WYCOFANIEZ RELACJI SPOŁECZNYCH \\
\hline POCZUCIE BRAKU SENSU ŻYCIA \\
POCZUCIE BEZWARTOŚCIOWOŚCI \\
\hline
\end{tabular}

Ryc. 6. Cechy charakterystyczne etapu depresji

Źródło: Wolski 2010, s. 34.

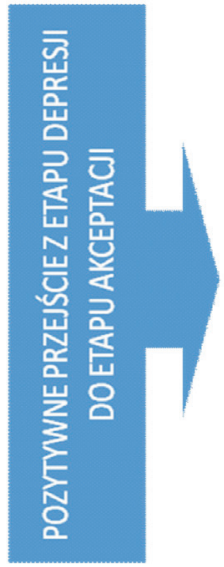

\begin{tabular}{l}
\hline ADAPTACJA DO NOWYCH WARUNKÓW \\
\hline DOSTRZEŻENIE NOWYCH MOŻLIWOŚCI \\
\hline WYZNACZENIE NOWYCH CELÓW \\
\hline PODEJMOWANIE AKTYWNYCH DZIAŁAŃ \\
\hline POWRÓT DO RELACJI SPOŁECZNYCH \\
\hline WYGASZENIE NEGATYWNYCHEMOCJI \\
REKONSTRUKCJA POCZUCIA TOŻSAMOŚCI \\
\hline
\end{tabular}

Ryc. 7. Cechy charakterystyczne etapu akceptacji

Źródło: Wolski 2010, s. 36.

- odczucie stawania się obcym samemu sobie oraz próby zbadania własnego obcego terytorium;

- osłabienie zdolności do nawiązywania i organizacji stosunków społecznych, co niesie ze sobą niebezpieczeństwo pogłębiającej się izolacji;

- egzystencjalny świat jednostki dotkniętej trajektorią wykazuje tendencję do kurczenia się i zanikania, przez co traci ona zdolność do funkcjonowania w kulturowo różnych światach społecznych, w których działanie nie sprawiało jej trudności; 
- rozstrój w sferze życia codziennego oraz stosunku osoby cierpiącej do władnej tożsamości i biografii;

- długotrwałe cierpienie otwiera przed jednostką szansę systematycznej refleksji, czego efektem mogą być schematy działania biograficznego służące opanowaniu trajektorii (Riemann, Schutze 1992).

\section{SCENARIUSZE WYJŚCIA Z TRAJEKTORII}

W literaturze podejmującej analizę etapów cierpienia można odnaleźć propozycje zakończenia tego procesu i wyjścia z trajektorii (por. Zakrzewska-Manterys 1995, Górecki 2007). Działania te mogą przybierać następujące formy:

- ucieczki od trajektorii, czyli ignorowania jej symptomów, nieprzyjmowania do wiadomości faktu zaistniałej sytuacji, czy też obniżanie jej rangi itp. ;

- „oswojenia” trajektorii, czyli w sytuacji gdy konsekwencje trajektorii nie mogą być zlikwidowane, może mieć miejsce włączenie trajektorii w indywidualną sytuację życiową człowieka, bez skupiania się na jej destrukcyjnym wpływie;

- eliminacji potencjału trajektoryjnego poprzez dokonanie całkowitej reorganizacji sytuacji życiowej, koncentracji na własnym rozwoju i wykorzystaniu tych traumatycznych doświadczeń do wzmocnienia własnych życiowych doświadczeń (Zakrzewska-Manterys 1995), tak aby człowiek na problem spojrzał z innego punktu widzenia, co jest jednak uwarunkowane całym przebiegiem życia jednostki.

\section{PRÓBY BADAŃ NAD TRAJEKTORIĄ CIERPIENIA OSÓB Z NAGŁĄ UTRATĄ SPRAWNOŚCI}

W rezultacie analizy teoretycznej nad trajektorią cierpienia osób z nagłą utratą sprawności powstaje konieczność podejmowania badań empirycznych dotyczących tego rodzaju problemów. Oczywiste jest, że podejmowana problematyka ma wymiar podmiotowy i indywidualny, i powinna stanowić szczególnie subtelną analizę procesu $z$ uwzględnieniem wielu uwarunkowań i zmiennych.

I tak prowadzone już badania na rozległej grupie 274 osób z ograniczeniami sprawności wykazują, że należy głównie wyodrębnić trzy fazy radzenia sobie z utratą sprawności (Wolski 2010), takie jak: zmagania się, depresji i akceptacji. Badania ujawniły również, że „oczekiwania osób niepełnosprawnych w kolejnych fazach radzenia sobie z utratą sprawności są zróżnicowane: w fazie zmagania się oczekiwane są działania informacyjne, w fazie depresji - wsparcie psychologiczne, a dopiero w fazie akceptacji - działania aktywizujące" (Wolski 2010, s. 136).

Prowadzone własne pilotażowe badania jakościowe na próbie 30 respondentów potwierdzają powyższe tezy z tą jednak różnicą, że w analizie indywidualnych biografii i negatywnych przeżyć badanych przede wszystkim dostrzega się 
często ukrywaną obniżoną samoocenę, obwinianie siebie, negatywne myślenie, poczucie bycia ofiarą, poczucie „straty” i bardzo często brak wiary w realizację planów oraz celów życiowych. Nagromadzenie negatywnych emocji i brak poczucia sprawstwa prowadzi często do wycofywania się z wielu sfer aktywności, rezygnacji z założeniem, że ,życie ulega całkowitej zmianie” i „brak jest możliwości radzenia sobie z utratą sprawności”, a w konsekwencji poczucie bezradności i braku sensu życia. Aktywna, pełna życzliwości i pomocy postawa bliskich, rodziny oraz instytucji ułatwia przystosowanie się do sytuacji trudnej. Należy również potwierdzić, że nabycie niepełnosprawności zmienia zakres samorealizacji i zakłóca rozwój, co znacząco potwierdzają badani, którzy dostrzegają związek ograniczeń w samorealizacji z sytuacją życiową. W lepszej jednak sytuacji są osoby, które nie stawiają własnej niepełnosprawności jako przeszkody na drodze do samorealizacji. Również lepsza sytuacja materialna, mieszkaniowa, opiekuńcza jest predykatorem lepszego zaspokajania potrzeb i dążeń osoby z nagłą utratą sprawności.

\section{ZAKOŃCZENIE}

Nadal pytaniem otwartym jest analizowany problem poprawy funkcjonowania osób z nagłą utratą sprawności. Co należy zrobić, jakie podejmować działania, aby trauma niepełnosprawności, kalectwa złagodziła ciężkie przeżycia i ułatwiła procesy adaptacyjne? Aby osoba z nagłą utratą sprawności nie żyła w przeświadczeniu, że utraciła wszystko? Warto jeszcze raz przypomnieć, że ,proces radzenia sobie z nagłą, albo przewlekłą chorobą lub niepełnosprawnością nabytą ma swoje etapy, a przebieg samego procesu ujmowanego jako całość ma charakter sekwencyjny i sinusoidalny - niektóre etapy cechują się znacznym wzrostem, a inne spadkiem energii oraz pozytywnych uczuć, takich jak na przykład nadzieja" (Wolski 2010, s. 8). Problemy rozwojowe, ale i egzystencjalne, opiekuńcze osób z nagłą utratą sprawności powinny być przedmiotem troski i zainteresowania wszystkich decydentów i instytucji pomocowych. Pokonywanie trudności, ale i uczenie się nowych zachowań, kompetencji, życia na nowo z niepełnosprawnością jest niewątpliwie wielkim wyzwaniem dla osoby nią dotkniętej, która często prezentuje postawy lękowe, pełne niepokoju i żalu po stracie, a jednocześnie uruchamia reakcje obronne.

Lekarz jak inżynier ma tę chorą część ciała zbadać i naprawić, może robić co chce, byle zbytnio nie bolało i byle swe zadanie spełnił. Cały ciężar odpowiedzialności spada na lekarza, chory jest biernym obserwatorem tego, co z jego ciałem poczynają. Nie bierze aktywnego udziału ani w procesie diagnostycznym, ani też leczniczym. Choć sam cierpi, cały dramat rozgrywa się jakby poza nim, bez jego aktywnego udziału. Jest widzem własnej choroby i jej leczenia. Jest to zazwyczaj widz wdzięczny, bo bardzo żywo interesuje się rozgrywającą się walką lekarza z chorobą (Kępiński 2013, s. 12). 
Jednak osoba, która doznaje bólu, cierpienia, głównie potrzebuje wsparcia emocjonalnego, doświadczając załamania czy rozpaczy.

Wymaga działania podtrzymującego, obecności innych osób, życzliwego zrozumienia, wysłuchania i pokrzepienia. Sam fakt towarzyszenia w niedoli „bycia razem”, troskliwości i gotowości do niesienia pomocy, jest wspieraniem emocjonalnym w trudach choroby i umierania. Odmianą wsparcia emocjonalnego jest wsparcie duchowe, polegające na oddziaływaniu psychologicznym na jednostkę będącą w stanie apatii, niemożności, rezygnacji, wyczekiwania czy załamania, aby poprzez to działanie starać się wzmocnić jej odporność psychiczną (Zych, Nowicka 2007, s. 17).

Bywa i tak, że lekarze odwlekają w czasie przekazywanie złych wiadomości, np. o niepełnosprawności, zostawiając zbyt duży zakres nadziei na wyzdrowienie. Do najczęstszych mechanizmów uniku prezentowanych przez lekarzy można zaliczyć:

- zasypywanie pacjentów medycznymi szczegółami,

- wielomówstwo w celu uniknięcia złowrogiej ciszy,

- wykonywanie wielu nieuzasadnionych badań dodatkowych,

- wysyłanie do lekarzy specjalistów,

- postawa obronna,

- oskarżanie pacjenta,

- obwinianie siebie,

- uniemożliwienie pacjentowi wyrażenia jego reakcji na złą wiadomość,

- brak empatii, zrozumienia dla stanu pacjenta,

- stwarzanie nierealnych nadziei,

- minimalizowanie negatywnych aspektów,

- nadmierne maksymalizowanie pozytywnych aspektów (M. Bujnowska-Fedak, M. Domański, A. Steciwko 1997, s. 83).

W sytuacji przekazywania złej wiadomości dotyczącej nagłej utraty sprawności oczekiwana jest sytuacja cierpliwego trwania z pacjentem, okazywanie mu zrozumienia, sygnalizowanie gotowości do udzielenia mu pomocy. Można tu wyróżnić następujące fazy przekazywania złej wiadomości:

1. Przekazanie złej wiadomości, udzielenie rzeczowej informacji.

2. Stawianie czoła reakcji pacjenta na otrzymaną trudną wiadomość:

- ujawnienie odczuć pacjenta,

- okazanie mu pełnego zrozumienia,

- zasygnalizowanie gotowości do udzielania pomocy,

- zasygnalizowanie gotowości do udzielenia mu wsparcia,

- ujawnienie własnych, przeżywanych z tym faktem emocji.

3. Zmierzenie się $\mathrm{z}$ problemem, czyli szukanie najlepszych rozwiązań, ujawnienie płynących z trudnej sytuacji konsekwencji, zaplanowanie dalszego postępowania. Ofiarowanie pacjentowi czasu dla otrząśnięcia się z reakcji szo- 
ku, wstępnego oswojenia się z nową, niezwykle trudną dla niego sytuacją (por. Bujnowska-Fedak, Domański, Steciwko 1997).

W budowaniu warunków pomocy, kompetentnego pomagania osobie z nagłą utratą sprawności warto postawić sobie następujące pytania:

- jakie strategie pomogą uzyskać to, czego potrzebuje, chce,

- jakie strategie są najlepsze w tej sytuacji,

- jakie strategie najlepiej pasują do jego możliwości,

- jakie strategie będą najbardziej opłacalne w wykorzystywaniu możliwości,

- jakie strategie są najskuteczniejsze,

- jakie strategie najlepiej odpowiadają preferowanym przeze mnie sposobom działania,

- jakie strategie są zgodne z moimi wartościami,

- jakie strategie będą miały najmniej niepożądanych skutków (por. Egan 1997).

W odkrywaniu wartości i sensu życia każdy człowiek dostrzega potrzebę dążeń do potencjalnego człowieczeństwa, samorealizacji, potrzeby afirmacji swojego życia na wartościach, w wierze i religii. Każdy człowiek, również z niepełnosprawnością, powinien odkrywać zagrożenia i szanse, sensownie decydować o swoim życiu, postępowaniu zgodnym z etyką i moralnością. Przy tym każda niepełnosprawność utrudnia normalne funkcjonowanie ale nie pozbawia osiaggania satysfakcji życiowej i nie przekreśla szansy człowieka na realizację postawionych sobie celów (por. W. Dykcik 2005).

\section{BIBLIOGRAFIA}

Bedyńska S., Rycielski P. (2010), Kim jestem? Przeciwdziałanie stereotypizacji i stygmatyzacji osób z ograniczeniami sprawności, Warszawa: Scholar.

Brzezińska A., Kaczan R., Smoczyńska K. (2010), Przekonania o swoim życiu. Spostrzeganie historii życia przez osoby z ograniczeniami sprawności, Warszawa: Scholar.

Bujnowska-Fedak M., Domański M., Steciwko A. (1997), Sztuka przekazywania trudnych wiadomości. Psychologiczne aspekty śmierci i umierania, [w:] J. Łazowski. G. Dolińska-Zygmunt (red.), Ku lepszemu funkcjonowaniu w zdrowiu i chorobie, Wrocław: Wydawnictwo AWF.

Cackowski Z. (1997), Ból, lęk, cierpienie, Lublin: Wydawnictwo UMCS.

Dobrowolska D. (1992), Przebieg życia - fazy - wydarzenia, „Kultura i Społeczeństwo”, 2.

Dykcik W. (2005), Pedagogika specjalna wobec aktualnych sytuacji i problemów osób niepetnosprawnych, Poznań: Wydawnictwo PTP.

Dykcik W. (2007), Zmieniająca się rzeczywistość jako źródło cierpień egzystencjalnych i moralnych czlowieka, [w:] A. A. Zych, A. Nowicka (red.), „By czlowiek nie musial cierpieć”, Księga jubileuszowa dedykowana Pani Profesor Aleksandrze Maciarz, Wrocław: Wydawnictwo Nauk. Dolnośląskiej Szkoły Wyższej.

Egan G. (1997), Kompetentne pomaganie, Poznań: Wyd. Zysk i S-ka.

Frankl V. E. (1984), Homo patiens, Warszawa: Instytut Wydawniczy PAX.

Górecki M. (2007), Trajektoria, [w:] T. Pilch (red.), Encyklopedia pedagogiczna XXI wieku, t. VI, Warszawa: Wydawnictwo Żak. 
Kępiński A. (2013), Poznanie chorego, Kraków: Wydawnictwo Literackie.

Kirenko J. (2002), Ocena życiowych możliwości psychofizycznych osób niepetnosprawnych, [w:] E. Rutkowska (red.), Rehabilitacja i pielegnowanie osób niepetnosprawnych. Podręcznik dla studentów pielęgniarskich studiów licencjackich, Lublin: Wydawnictwo Czelej.

Kowalik S. (2003), Dorosłość osób niepelnosprawnych w świetle koncepcji sfery utraconego rozwoju, [w:] K. Rzedziecka, A. Kobylańska (red.), Dorostość, niepetnosprawność, czas wspótczesny. Na pograniczu pedagogiki specjalnej, Kraków: Impuls.

Lewandowska (1997), Trajektoria cierpienia matek dziecka z autyzmem, [w:] C. Kosakowski, A. Krause, S. Przybyliński (red.), Pomiędzy teoria a praktyka, Olsztyn: Wyd. UWM.

Nowak-Lipińska (2007), Mam upośledzona umystowo matke - rzecz o trajektorii cierpienia, [w:] T. Sołtysiak, M. Gołębiowska (red.), Zagrożenia i zaburzenia funkcjonowania polskich rodzin, Włocławek: Wyd. Wyższa Szkoła Humanistyczno-Ekonomiczna.

Olearczyk T. (2007), Wybrane aspekty cierpienia. Czego może uczyć cierpienie? [w:] G. Makiełło-Jarża, Z. Gajda (red.), Ból i cierpienie, Kraków: Wydawnictwo Krakowskie Towarzystwo Edukacyjne Oficyna AFM.

Riemann G., Schütze (1992), Trajektoria jako podstawowa koncepcja teoretyczna w analizach cierpienia i bezładnych procesów społecznych, „Kultura i Społeczeństwo”, 2.

Schütze F. (1997), Trajektorie cierpienia jako przedmiot badań socjologii interpretatywnej, „Studia Socjologiczne", 1.

Ślęzak M. (2005), Trajektoria cierpienia jako kategoria analizy w badaniach etnicznych (propozycje badań), [w:] J. Leoński, A. Kołodziej-Duraś (red.), W kręgu socjologii interpretatywnej - zastosowanie metod jakościowych, Szczecin: Wydawnictwo Economicus.

Strauss A. L. (1989), The Rebirth of Classical Political Rationalism. An Introduction to the Thought of Leo Strauss. Essays and Lectures by Leo Strauss, Chicago: Wydawnictwo Aldine Publisching Co.

Wikliński (2010), Modele niepetnosprawności - indywidualny i funkcjonalny, [w:] A. I. Brzezińska, R. Kaczan, K. Smoczyńska (red.), Diagnoza potrzeb i modele pomocy dla osób z ograniczeniami sprawności, Warszawa: Scholar.

Wolski P. (2010), Utrata sprawności. Radzenie sobie z niepetnosprawnościq nabytą a aktywizacja zawodowa, Warszawa: Scholar.

Zakrzewska-Manterys E. (1995), Down i zespót wątpliwości. Studium z socjologii cierpienia, Warszawa: Wydawnictwo Naukowe Sember.

Zawiła (2008), Religia i śmierć. Trajektoria i jej religijne aspekty na przyktadzie środowisk hospicyjnych $w$ Polsce, Kraków: Wyd. NOMOS.

Zych A. A., Nowicka A. (2007), „By człowiek nie musiał cierpieć ...” Księga jubileuszowa dedykowana Pani Profesor Aleksandrze Maciarz, Wrocław: Wydawnictwo Naukowe Dolnośląskiej Szkoły Wyższej.

\section{SUMMARY}

In accordance with the achievements of modern science, especially medicine, psychology, genetics and special education, a contemporary human - as the main being in the modern world - is able to overcome many constraints and problems, existential crises, difficult situations, pain and suffering. The occurrence of a sudden disability, however, changes the situation completely, causing a lot of negative experiences and becomes the process of trajectorical struggle with fear, rejection, loneliness and the search for the value of suffering, but also an attempt to accept oneself in new roles and limitations of existence.

Key words: acquired disability, existential crises, process of trajectorical struggle 